\title{
Experimental testing of exterior wall mounted mechanical ventilation exhaust air outlet devices
}

\author{
Ülar Palmiste ${ }^{1 *}$, Tauno Meier ${ }^{1}$, Jarek Kurnitski ${ }^{1,2}$ and, Hendrik Voll ${ }^{1}$ \\ ${ }^{1}$ Tallinn University of Technology, Department of Civil Engineering and Architecture, Ehitajate tee 5, 19086 Tallinn, Estonia \\ ${ }^{2}$ Aalto University, School of Engineering, Rakentajanaukio 4 A, FI-02150, Espoo, Finland
}

\begin{abstract}
The purpose of the study was to experimentally test the performance of four types of wallmounted mechanical ventilation exhaust air outlet devices. A full-scale mock-up of a segment of an external wall with an exhaust air outlet was constructed. The tested exhaust air devices include a gravity louver, fixed-blade louver, louver plate, and exhaust nozzle. The performance assessment included two types of experiments over the exhaust airflow rate range of 25-94 1/s at isothermal conditions with no influencing wind: (i) the particle tracer method with smoke to visualize the exhaust air jets from the outlets, and (ii) the tracer gas method to measure the dilution of $\mathrm{CO}_{2}$ concentration in the exhaust air jet. Furthermore, the aerodynamic performance was comparatively evaluated in terms of pressure drop and exhaust air face velocity at the outlet. The qualitative comparison of airflow patterns by smoke visualization showed notable differences between the tested device types. Concentration decrease evaluation indicated that the exhaust air pollutants are more efficiently transported away from the building wall by exhaust outlets that discharge at 0-45 degrees downwards from the horizontal plane. Discharge angles 60-90 degrees downwards produced a wall-attached jet and the pollutant tracer concentration remained relatively high in the vicinity of the wall.
\end{abstract}

\section{Abbreviations and symbols}

$\begin{array}{ll}\mathrm{AHU} & \text { air-handling unit } \\ \mathrm{CO}_{2} & \text { carbon dioxide } \\ \mathrm{DV} & \text { decentralized ventilation } \\ \mathrm{A}_{\text {eff }} & \text { exhaust outlet effective area, } \mathrm{m}^{2} \\ \mathrm{C}_{\mathrm{ex}} & \text { concentration at the exhaust outlet, ppm } \\ \mathrm{C}_{\mathrm{r}} & \text { concentration at the receptor, ppm } \\ \mathrm{C}_{0} & \text { background concentration, ppm } \\ \mathrm{f} & \text { percentage fraction, } \% \\ \mathrm{~V}_{\text {duct }} & \text { air velocity in duct, } \mathrm{m} / \mathrm{s} \\ \mathrm{V}_{\text {face }} & \text { face velocity, } \mathrm{m} / \mathrm{s} \\ \mathrm{Q} & \text { volumetric airflow rate, } 1 / \mathrm{s} ; \mathrm{m}^{3} / \mathrm{s} \\ \rho & \text { air density, } \mathrm{kg} / \mathrm{m}^{3} \\ \Delta \mathrm{p} & \text { pressure drop, Pa }\end{array}$

\section{Introduction}

The European Union has established legislative measures to mitigate the negative environmental effects of the building sector by setting binding energy efficiency [1] and decarbonization [2] targets. In colder climates, the shift in conventional building practice to comply with the stringent building performance regulations means, among other things, the improvement of building enclosures to achieve energy efficiency, thermal comfort, and moisture safety. Furthermore, the higher requirements of building airtightness impose higher demands on ventilation, which leads to a wider implementation of balanced mechanical ventilation with heat recovery that has been shown to be favorable in colder climates compared to natural ventilation and mechanical exhaust ventilation in terms of primary energy, carbon dioxide emission and operating energy cost [3]-[6].

Decentralized ventilation (DV) configuration with an apartment-based air-handling unit (AHU) is an increasingly common mechanical ventilation solution in multifamily residential dwellings. With DV, typically no section of the air distribution network is shared for the whole building, which can present a design hurdle for locating outdoor air intake and exhaust air outlet devices and the ducting between the outdoor terminal devices and AHU. A common approach is to use vertical duct runs through the building to exhaust outlet devices above the roof, but discharging exhaust air through an external wall is an advantageous system design alternative as it could help to achieve savings in investment and operating costs and, vertical ducts require space that cannot be used for alternative floor space usages [7]. Ventilation engineers base their design decisions on the regulatory framework and topical technical guidance documents. However, there is inconsistency among both European national regulations and international standards and codes for the placement of residential ventilation exhaust air devices [8], [9]. In addition, a study by the HVAC Association of Finland (SuLVI) proposed that the design requirements for locating exhaust air outlets and outdoor air intakes on the same external wall should be critically investigated and reevaluated, chiefly in the case where they are part of a decentralized ventilation system

* Corresponding author: ular.palmiste@ taltech.ee 
serving an apartment or a specific space of the building [7]. The existing applicable design guidelines published in the technical engineering literature, including international standards, codes, and guidebooks were reviewed by Palmiste et al. (2020) [9].

There are very few experimental studies on the performance of wall-mounted exhaust air devices. Luoma et al. studied odor dispersion from a kitchen exhaust outlet on a wall [10]. Broas (1993), Kovanen et al. (1994), and Broas (1996) studied the re-entrainment of exhaust air into intakes located on the same external wall in full-scale and wind tunnel experiments [11][13]. Parker et al. (2014) tested a wall-mounted exhaust vent in a full-scale laboratory model of two vertically oriented apartment units to evaluate the re-entrainment risk [14]. Sibille (2015) tested a coaxial duct as an outdoor air intake and an exhaust air outlet for apartment-based AHU [15]. The exhaust air device type significantly influences the exhaust air pattern and nearfield pollutant dispersion in the vicinity of the building enclosure. However, only two studies specified the exhaust air outlet device they used in their experiments.

The purpose of this study was to experimentally test the performance of four types of wall-mounted exhaust air outlets. Specifically, a full-scale model of an exterior wall was applied to qualitatively assess the exhaust airflow pattern from different exhaust air devices with smoke visualization, and quantitatively determine the decrease of pollutant concentration in the exhaust air stream at several locations downstream the exhaust outlet. The aerodynamic performance of the studied devices was evaluated concerning relevant ventilation design parameters.

\section{Methods}

\subsection{Exhaust air outlet devices}

The exhaust air devices that were used in the experimental testing are depicted in Figure 1.

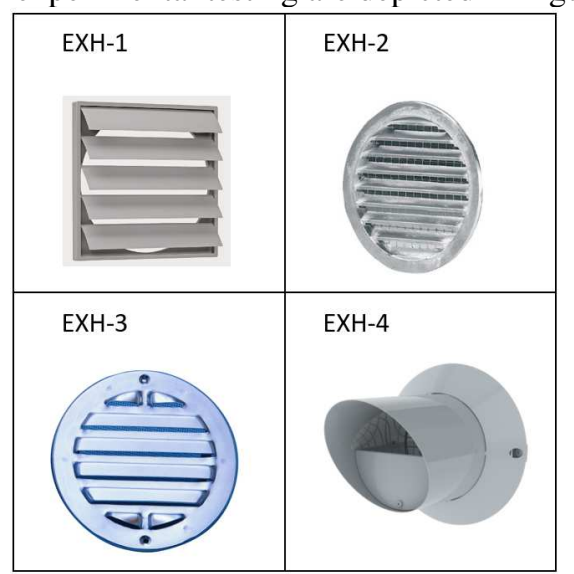

Figure 1. Tested exhaust air outlet devices. Product names EXH-1 - VK; EXH-2 - USAV; EXH-3 - USSV; EXH-4 - NPC.

The significant variation of construction features among exhaust outlets affects the effective area (the net area through which air can pass within the exhaust air device) and exhaust air discharge angle. The specification of the tested exhaust air outlet devices is presented in Table 1. The devices had the same nominal size $\varnothing 160 \mathrm{~mm}$ (dimension of the duct opening into which the exhaust air device is installed). The discharge angle of a gravity louver changes depending on the flow rate and the blades will close automatically limiting air backdraft and water penetration and ingress of foreign objects. Louver with inclined fixed blades discharges exhaust air at an angle depending on the position of the louver blades. A louver plate is an exhaust air device that has a downward linear slot that is covered on the other three sides. Nozzle-type outlet terminates the exhaust perpendicularly outward from the wall face. The tested nozzle dimensions were $255 \mathrm{~mm}$ (top length) and 163 $\mathrm{mm}$ (bottom length).

Table 1. Specification of exhaust air devices

\begin{tabular}{|c|c|c|c|}
\hline $\begin{array}{l}\text { Device } \\
\text { No. } \\
\end{array}$ & Device type & $\begin{array}{c}\text { Deflector } \\
\text { position }\end{array}$ & $\begin{array}{l}\text { Effective } \\
\text { area, } \mathbf{m}^{2}\end{array}$ \\
\hline EXH-1 & $\begin{array}{l}\text { gravity } \\
\text { louver }\end{array}$ & $\begin{array}{l}\text { approx. } 5 \text { to } \\
85^{\circ} \text { downward }\end{array}$ & $\mathrm{n} / \mathrm{a}$ \\
\hline EXH-2 & $\begin{array}{c}\text { fixed-blade } \\
\text { louver }\end{array}$ & $30^{\circ}$ downward & $\mathrm{n} / \mathrm{a}(0.012 *)$ \\
\hline EXH-3 & louver plate & $\begin{array}{l}90^{\circ} \text { downward } \\
\text { (parallel to the } \\
\text { wall) }\end{array}$ & $\mathrm{n} / \mathrm{a}$ \\
\hline EXH-4 & nozzle & $\begin{array}{l}\text { horizontal } 0^{\circ} \\
\text { (perpendicular } \\
\text { to wall) }\end{array}$ & $\mathrm{n} / \mathrm{a}(0.02 *)$ \\
\hline
\end{tabular}

\subsection{Experimental setup and design}

The experiments were performed using a mock-up of an external wall that was constructed in an indoor unconditioned facility with a floor area of approximately $90 \mathrm{~m}^{2}$ and a volume of $435 \mathrm{~m}^{3}$. The experimental setup is shown in Figure 2. The external wall was fabricated using plywood boards. The wall had five openings with a diameter of $160 \mathrm{~mm}$ for installing either exhaust air outlets or air intakes. The equipment for controlling the airflow and tracer gas injection was arranged behind the wall as can be seen in Figure 3. The airflow was produced by an inline fan (K $160 \mathrm{XL})$ with a speed controller. The volumetric flow rate was measured with a pressure differential sensor (CPS-D-A) from an iris-type damper.

The tracer particle method was utilized to obtain qualitative information on exhaust airflow. The exhaust air stream was seeded with tracer particles of smoke and the resulting cloud of tracer particles made flow patterns visible which were visually captured on instantaneous snapshots with a camera. Smoke cartridges (SMOKEDEC SM045) were used at the opening of the air intake duct to produce grayish-white smoke with almost the same density as air. The room walls were covered with black polyethylene plastic sheeting for high contrast background to improve the flow visualization. Besides, the plastic sheeting helped to 


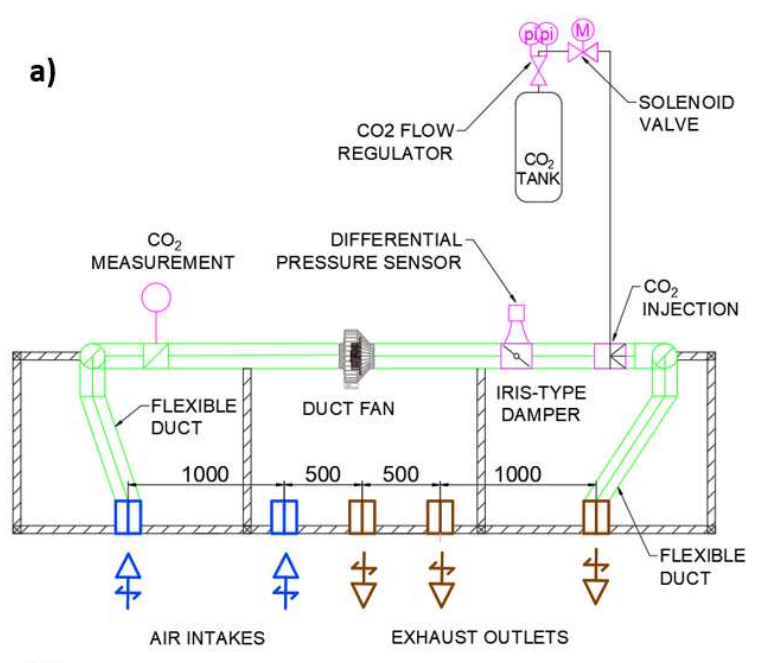

b)

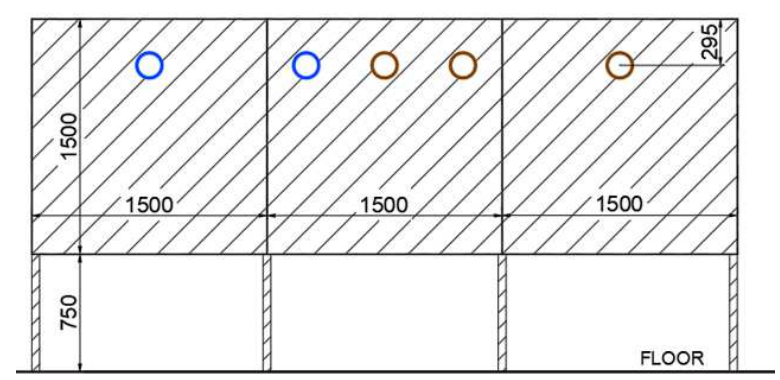

Figure 2. Schematic of the experimental setup: a) top view, b) front view.

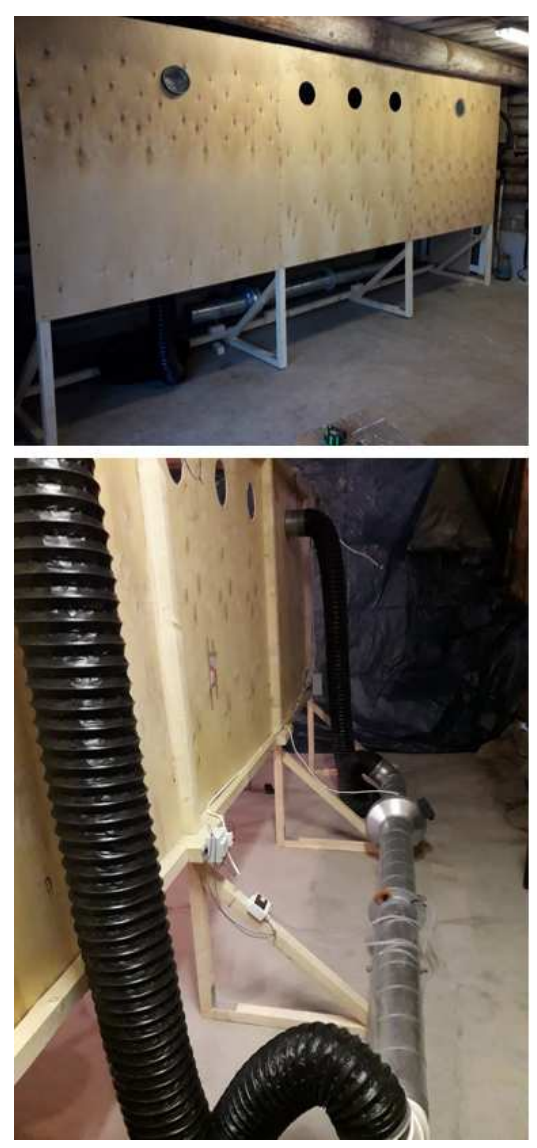

Figure 3. Experimental mock-up: front view (top) and side view (bottom). minimize the potential negative effects of wind-induced infiltration into the test room.

Carbon dioxide $\left(\mathrm{CO}_{2}\right)$ was used as a tracer gas to simulate the pollutants in the exhaust air stream. A controlled amount $(10,5 \mathrm{l} / \mathrm{min})$ of $\mathrm{CO}_{2}$ was injected into the exhaust airflow from a $\mathrm{CO}_{2}$ tank to measure the resulting concentration at several locations in front of the test wall.

The following measuring equipment was used for data collection:

- $\mathrm{CO}_{2}$ data loggers HOBO MX1102A;

- differential air pressure sensor CPS-D-A Calectro.

The testing was conducted indoors instead of outdoors to simulate stable atmospheric conditions with minimal uncontrolled air movement. The tests were performed under isothermal conditions with a neutrally buoyant exhaust jet and no influencing wind. The indoor temperature in the unconditioned test facility ranged from 13 to $17^{\circ} \mathrm{C}$ over a period of days, but the maximum temperature difference for a single day was not more than $2^{\circ} \mathrm{C}$.

In this study, 11 experimental scenarios were investigated. The summary of the experimental scenarios is presented in Table 2 .

Table 2. Summary of the experimental scenarios

\begin{tabular}{|c|c|c|c|c|}
\hline No. & $\begin{array}{c}\text { Exhaust } \\
\text { outlet } \\
\text { type }\end{array}$ & $\begin{array}{c}\text { Flow } \\
\text { rate, } \\
\text { 1/s }\end{array}$ & $\begin{array}{c}\text { Measurement } \\
\text { sessions }\end{array}$ & $\begin{array}{c}\text { Sampling } \\
\text { points }\end{array}$ \\
\hline 1 & EXH-1 & 27 & 6 & 16 \\
\hline 2 & EXH-1 & 52 & 6 & 16 \\
\hline 3 & EXH-1 & 94 & 15 & 42 \\
\hline 4 & EXH-2 & 27 & 12 & 34 \\
\hline 5 & EXH-2 & 52 & 15 & 46 \\
\hline 6 & EXH-2 & 91 & 11 & 27 \\
\hline 7 & EXH-3 & 25 & 5 & 13 \\
\hline 8 & EXH-3 & 52 & 6 & 16 \\
\hline 9 & EXH-4 & 27 & 29 & 84 \\
\hline 10 & EXH-4 & 51 & 19 & 55 \\
\hline 11 & EXH-4 & 94 & 20 & 58 \\
\hline
\end{tabular}

In total, the measurement campaign consisted of 144 experimental sessions during which time-series concentration data for 407 sampling points was obtained. The sampling rate was 1 second and the sampling period was $\sim 50$ seconds. Before the experimental sessions, smoke tests were performed to determine the experimental sampling point locations that would capture the exhaust air jet at different flow rates. All $\mathrm{CO}_{2}$ sampling points were located on the vertical plane in the middle of the exhaust air device in front of and perpendicular to the test wall surface. For each exhaust device, there was one session with a sampling point in the exhaust outlet location to measure the exhaust concentration, and the rest of the sampling points were located in the test room. Measurements in front of the test wall were conducted using simultaneously three $\mathrm{CO}_{2}$ loggers that were relocated after each session. During the first 10-15 seconds, the background concentration was recorded and then the $\mathrm{CO}_{2}$ injection to the exhaust air stream was started. The time lag between experimental sessions was 5 minutes during which the test facility was flushed to reattain the 
ambient $\mathrm{CO}_{2}$ concentration level, and the measured data from the loggers were exported to a laptop computer and the data loggers were relocated.

\subsection{Data analysis}

The logged concentration time series data with position coordinates for each sampling point were compiled into a spreadsheet database. Next, the minimum and maximum concentration values were extracted from the raw dataset and were defined as the background concentration for the receptor (data logger at the sampling point) and worst-case concentration for receptor concentration, respectively, for each sampling point. The same procedure was followed to determine the background concentration and exhaust air concentration at the exhaust outlet.

The exhaust outlet concentration varied between the scenarios, being greatest at low flow rates, and thus, the concentration results are normalized to the exhaust air concentration. The previously defined concentration values were used to calculate the remaining tracer gas concentration at the receptor, which is represented as a percentage fraction of the initial concentration as follows:

$$
f=\left(C_{r}-C_{0}\right) /\left(C_{e x}-C_{0}\right)
$$

where $\mathrm{f}$ is the percentage fraction $(\%), \mathrm{C}_{\mathrm{r}}$ is the measured tracer gas concentration at the receptor (ppm), $\mathrm{C}_{\mathrm{ex}}$ is the measured tracer gas concentration at the exhaust outlet (ppm), and $\mathrm{C}_{0}$ is the background concentration (ppm).

The relationship between the aerodynamic pressure drop in the exhaust air device and exhaust air volumetric flow rate was derived from the manufacturers' technical datasheets. The effective area of the exhaust air device is calculated as follows:
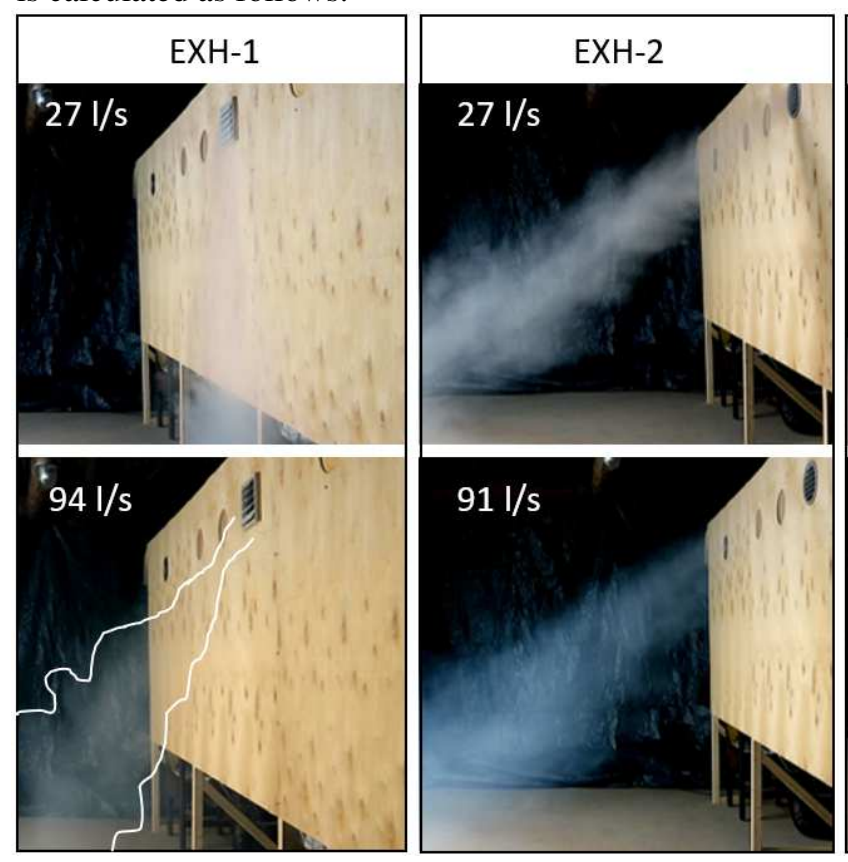

$$
A_{e f f}=Q \cdot \sqrt{\frac{\rho}{2 \cdot \Delta p}}
$$

where $A_{\text {eff }}$ is the effective area $\left(\mathrm{m}^{2}\right), \rho$ is the air density $\left(\mathrm{kg} / \mathrm{m}^{3}\right)$ and $\Delta \mathrm{p}$ is the pressure drop across the exhaust air device $(\mathrm{Pa})$ and $\mathrm{Q}$ is the volumetric flow rate $\left(\mathrm{m}^{3} / \mathrm{s}\right)$. Air density of $1,225 \mathrm{~kg} / \mathrm{m}^{3}$ was assumed in this study.

Face velocity $V_{\text {face }}(\mathrm{m} / \mathrm{s})$ is calculated as:

$$
V_{\text {face }}=Q / A_{\text {eff }}
$$

\section{Results and discussion}

\subsection{Exhaust airflow visualization}

The smoke visualization of air jets from wallmounted exhaust air devices is useful to communicate qualitative information about the exhaust flow patterns. Figure 4 presents the instantaneous snapshots of exhaust airflow patterns obtained with different exhaust air devices. The gravity louver EXH-1 discharge direction depends on the exhaust airflow rate. At low flow rates, the air stream behaves like a wall jet as it is attached to the façade, but at higher flow rates the flow separates from the wall surface and forms a turbulent free jet. The exhaust jet deflection angle of fixed-blade louver EXH2 is determined by the fixed position of the blades. Louver plate EXH-3 produces a downward wallattached exhaust airflow. Exhaust nozzle EXH-4 develops an isothermal turbulent free jet because there are no obstructions to the flow inside the exhaust device.

Figure 4. Instantaneous images of the exhaust airflow patterns produced by different exhaust air devices (smoke visualization). 

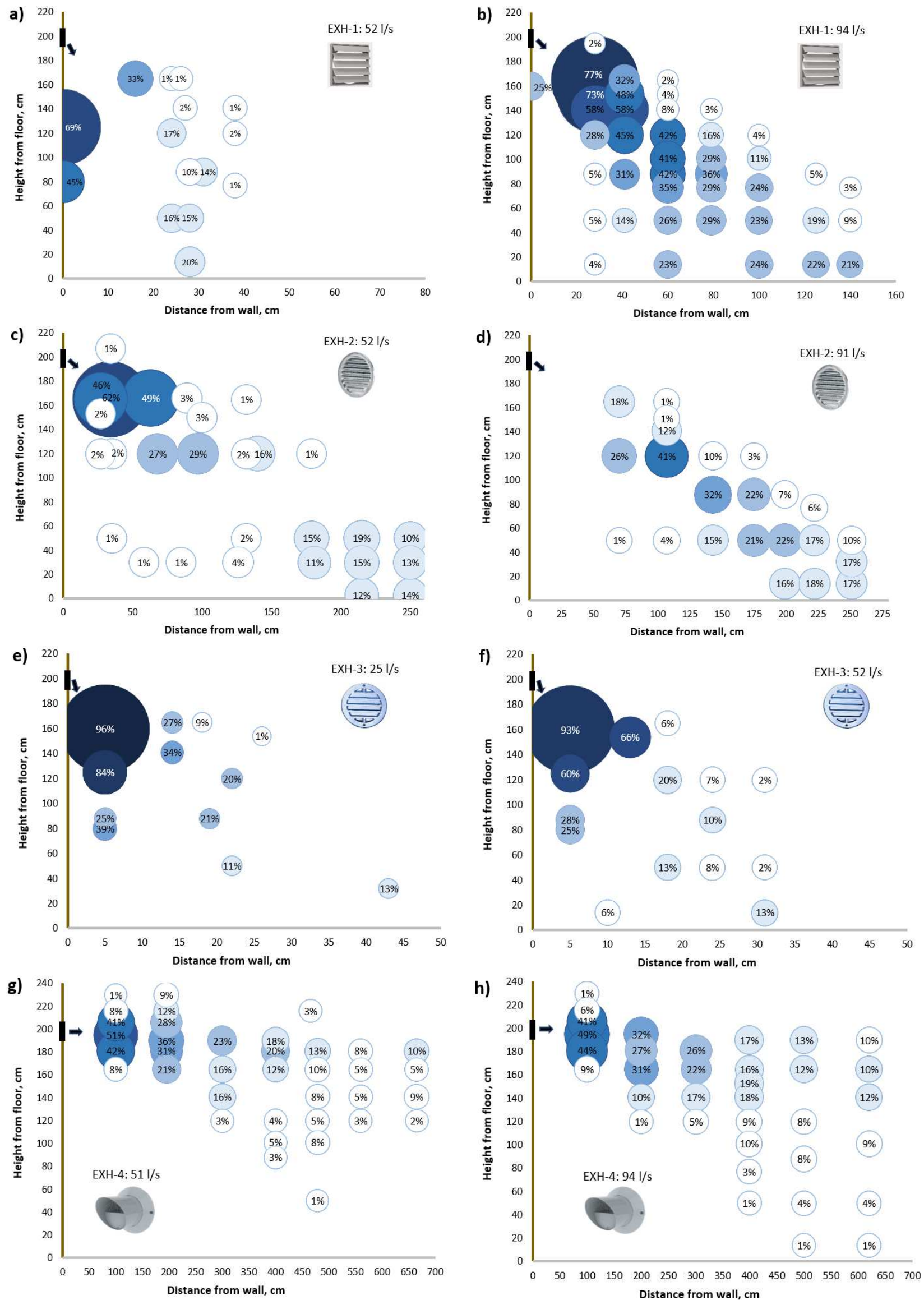

Figure 5. The remaining tracer gas concentration as a fraction of the initial exhaust concentration, expressed as a percentage. Figure key: darker colors and larger bubbles indicate lower dilution; lighter colors and smaller bubbles indicate higher dilution. 


\subsection{Pollutant tracer dilution}

Pollutant tracer concentration decreases with the distance from the exhaust outlet because the jet entrains the surrounding outdoor air that slows the airflow and dilutes the concentration within the jet. Figure 5 shows the concentration decrease from the wall-mounted exhaust outlet. The vertical axis depicts the vertical cross-section of the test wall with the center of the exhaust outlet located at a height of $1955 \mathrm{~mm}$ from the floor. The horizontal axis shows the horizontal distance from the wall. Concentration is represented as a percentage fraction of the initial concentration remaining in the sampling points. As it could be expected, the lowest concentration decrease was close to the exhaust jet centerline. When the exhaust discharge angle is in the range of approximately 0-45 degrees downwards, then the remaining tracer gas concentration in the close vicinity $(<1 \mathrm{~m})$ of the wall is low regardless of the tested flow rates, see plots c-d and g-h in Figure 5. Device EXH-4 that discharges horizontally is especially efficient in transporting exhaust air pollutants away from the building façade. From plots a-b and e-f it can be seen that for the discharge angles 45-90 degrees downwards, the concentration remains relatively high near the wall. The exhaust air seems to attach to the wall when the exhaust angle is in the range of 60-90 degrees.

Spot-check measurements of tracer gas concentration at the air intake that was located horizontally 2 meters from the exhaust outlet showed no occurrence of re-entrainment under isothermal conditions with no wind. From Figure 5 it can be inferred that under isothermal conditions with very low wind speed, the exhaust air could re-enter the building via an air intake or other outdoor air opening located up to 2 meters below the exhaust outlet.

More research is needed to include the wind influence and buoyancy effects due to the temperature difference between the exhaust air and outdoor air. Concentration should be measured at different locations around the exhaust outlet to assess the re-entrainment risk.

\subsection{Aerodynamic performance}

Aerodynamic performance is an important consideration because it affects the building's electrical energy consumption. The greater the pressure drop, the more fan power is required to move the same volumetric airflow rate. The face velocity increases in the exhaust air device because the free area is smaller than the crosssectional area of the connected duct due to construction features like blades, frame elements, mullions, structural supports, screens, and others. Pressure drop caused by exhaust airflow through the tested exhaust air devices is depicted in Figure 6. Plots of the approximated face velocity at the opening of the exhaust device versus exhaust air velocity and flow rate in the connected duct are presented in Figure 7. Devices EXH-1 and EXH-4 perform similarly in terms of pressure drop and face velocity at the outlet regardless of the distinctive constructional features. Devices EXH-2 and EXH-3 cause higher flow resistance due to features such as airflow deflection blades and deflector plate that create a constriction upon the flow and thus, limit the discharge outlet effective area.

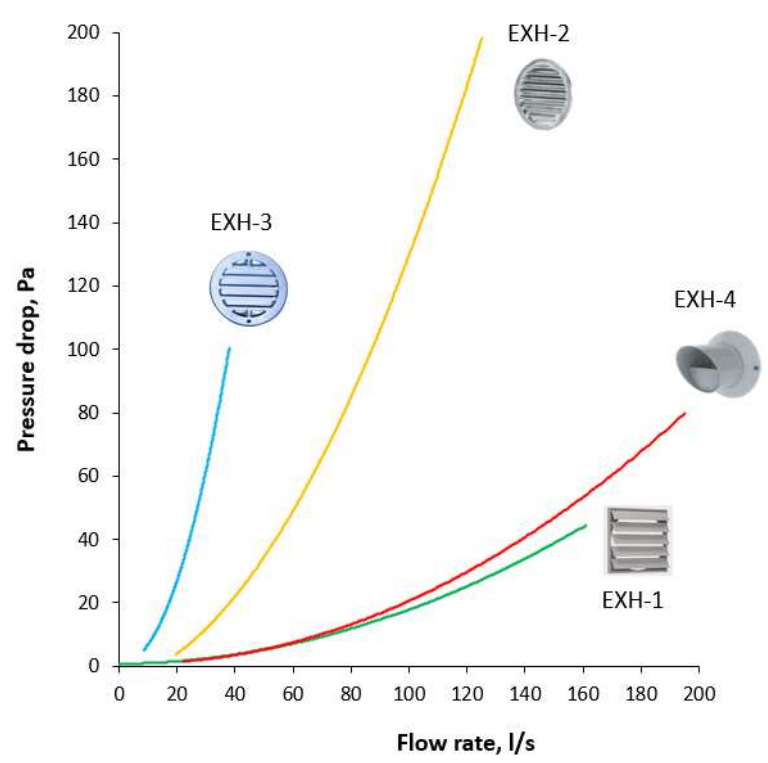

Figure 6. Aerodynamic pressure drop at different flow rates.

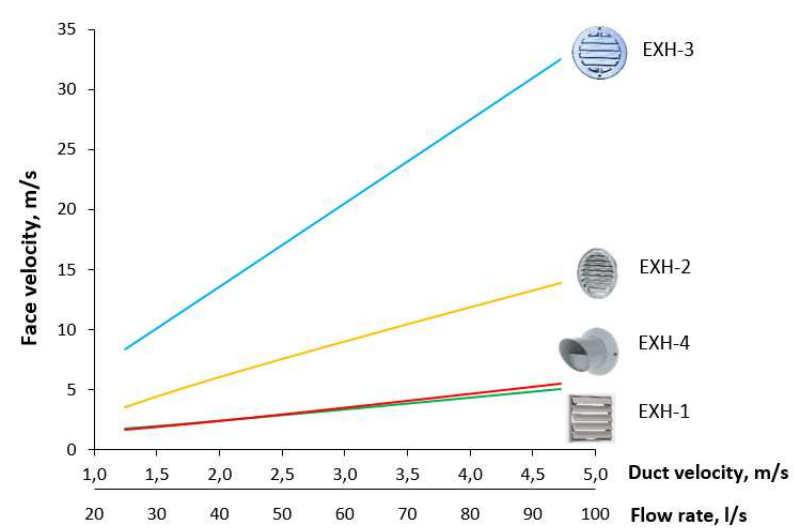

Figure 7. Approximated face velocity versus velocity and flow rate in the upstream duct.

The aerodynamic performance of the exhaust air devices was evaluated analytically as described in section 2.3. Flow performance metrics for the test scenarios are summarized in Table 3 . The volumetric flow rate was measured from the damper after the fan. Manufacturer technical datasheets were utilized to determine the pressure drop in the exhaust air devices for specified flow rates. Duct velocity $V_{\text {duct }}$ was calculated from the flow rate and cross-sectional area of the connecting $160 \mathrm{~mm}$ round duct. The cross-sectional area for a round duct with a diameter of $160 \mathrm{~mm}$ is 0.02 $\mathrm{m}^{2}$. The effective area is a product of the outlet free area and the coefficient of discharge, which was mostly unknown for the tested exhaust terminals. Therefore, the 
face velocity in the effective area of the exhaust device was indirectly approximated using Equations 2 and 3.

Table 3. Aerodynamic performance of tested scenarios

\begin{tabular}{|c|c|c|c|c|c|c|}
\hline No. & Type & $\begin{array}{l}\mathbf{Q}, \\
\mathbf{l} / \mathrm{s}\end{array}$ & $\Delta \mathrm{p}, \mathbf{P a}$ & $\begin{array}{c}\mathbf{A}_{\text {eff }}, \\
\mathbf{m}^{2}\end{array}$ & $\begin{array}{c}\mathbf{V}_{\text {duct, }}, \\
\mathbf{m} / \mathbf{s}\end{array}$ & $\begin{array}{c}\mathbf{V}_{\text {face }} \\
\mathrm{m} / \mathrm{s}\end{array}$ \\
\hline 1 & EXH-1 & 27 & 2.1 & 0.014 & 1.3 & 1.9 \\
\hline 2 & EXH-1 & 52 & 5.5 & 0.017 & 2.6 & 3.0 \\
\hline 3 & EXH-1 & 94 & 15.7 & 0.019 & 4.7 & 5.1 \\
\hline 4 & EXH-2 & 27 & 9.3 & 0.007 & 1.3 & 3.9 \\
\hline 5 & EXH-2 & 52 & 37.4 & 0.007 & 2.6 & 7.8 \\
\hline 6 & EXH-2 & 91 & 108.8 & 0.007 & 4.5 & 13.3 \\
\hline 8 & EXH-3 & 25 & 42.7 & 0.003 & 1.2 & 8.4 \\
\hline 9 & EXH-3 & 52 & $190.6^{*}$ & 0.003 & 2.6 & 17.6 \\
\hline 10 & EXH-4 & 27 & 2.0 & 0.015 & 1.3 & 1.8 \\
\hline 11 & EXH-4 & 51 & 5.6 & 0.017 & 2.5 & 3.0 \\
\hline 12 & EXH-4 & 94 & 18.4 & 0.017 & 4.7 & 5.5 \\
\hline
\end{tabular}

Some guidelines propose a minimum exhaust air velocity for wall exhausts, see Palmiste et al. (2020) for details [9]. Commonly, the product datasheet includes a selection nomogram which establishes a relationship between pressure drop and either velocity or flow rate in the upstream duct. To assess compliance with the exhaust velocity requirement, the specific product's effective area or free area and discharge coefficient should also be reported. Unfortunately, this information is often lacking based on the experience conducting the aerodynamic performance assessment for the current study. The effective area was reported for none of the tested exhausts. Two tested exhaust outlets had information on the free area, but this is deficient to calculate the correct face velocity because the constriction to airflow caused by the geometric features of the outlet should also be taken into account as it limits the area where the fluid (exhaust air) can flow through. Jones et al. (2016) proposed that the effective area which should be determined by laboratory measurements under controlled conditions for a specific exhaust air device model and size should be reported in technical specification datasheets as a best practice [16].

Existing design guidelines could be improved to consider the specific characteristics of different exhaust air types. For example, in the technical report for ventilation in non-residential buildings CEN/TR 167984 [17], it is recommended that the intake opening should be at least 2 meters below the discharge opening in the same wall, but based on the current study it could be specified that this is applicable for exhaust outlets with a discharge angle between 0-45 degrees.

\section{Conclusions}

This study investigated the performance of four types of external wall-mounted exhaust air devices in a full-scale mock-up of an external wall in a laboratory setting. The experiments included qualitative visualization of exhaust discharge flow patterns for given flow rates and measurements of tracer gas concentration downstream of the exhaust outlet to evaluate the concentration decrease dynamics with different types of exhaust air devices. The aerodynamic performance of the studied exhaust terminals was characterized analytically for the tested exhaust scenarios using manufacturers' technical datasheets. The main results can be summarized as follows:

- The characteristic construction features significantly affect the exhaust jet discharge angle and flow pattern.

- The exhaust air pollutants are more efficiently transported away from the building wall by exhaust outlets that discharge at angles 0-45 degrees downwards from the horizontal plane.

- Discharge angles 60-90 degrees downwards produced a wall-attached jet and the pollutant tracer concentration remained relatively high near the wall.

- The ranking of devices based on the results of this study considering both exhaust pollutant removal and aerodynamic performance is the following: 1) exhaust nozzle, 2) fixed-blade louver, 3) gravity louver, 4) louver plate.

The interpretation of the results obtained in this work must consider the study limitations: tested exhaust air device types and sizes, isothermal condition, neutrally buoyant exhaust jet, and exhaust airflow rate in the range of $25-94 \mathrm{l} / \mathrm{s}$.

Future research work involves measurements of exhaust pollutant dispersion with simulated side-wind effect and parametric CFD analysis of practical design cases to develop a knowledge basis to evaluate the reliability of current design guidelines.

This research was supported by the Estonian Research Council, with Personal research funding grant PUT-652 and by the Estonian Centre of Excellence in Zero Energy and Resource Efficient Smart Buildings and Districts, ZEBE (grant No. 2014-2020.4.01.15-0016) funded by the European Regional Development Fund.

\section{References}

[1] European Union, "Directive (EU) 2018/844 of the European Parliament and of the Council of 30 May 2018 amending Directive 2010/31/EU on the energy performance of buildings and Directive 2012/27/EU on energy efficiency (Text with EEA relevance)," Off. J. Eur. Union, vol. 61, no. L 156, pp. 75-91, 2018.

[2] European Commission, "Energy Roadmap 2050," Publications Office of the European Union. pp. 1-24, 2012.

[3] J. Laverge and A. Janssens, "Heat recovery ventilation operation traded off against natural and simple exhaust ventilation in Europe by primary energy factor, carbon dioxide emission, household consumer price and exergy," Energy Build., vol. 50, pp. 315-323, 2012.

[4] D. Suszanovicz, "Optimisation of Heat Loss through Ventilation for Residential Buildings," 
Atmosphere (Basel)., vol. 9, no. 3, 2018.

[5] J. Zemitis, A. Borodinecs, and T. Kalamees, "Analysis of various ventilation solutions for residential and non-residential buildings in Latvia and Estonia," Cold Clim. HVAC 2018 Sustain. Build. Cold Clim., no. March, pp. 5161, 2019.

[6] J. Jokisalo, J. Kurnitski, M. Vuolle, and A. Torkki, "Performance of Balanced Ventilation with Heat Recovery in Residential Buildings in a Cold Climate," Int. J. Vent., vol. 2, no. 3, pp. 223-236, 2003.

[7] O. Seppänen, J. Railio, and T. Strand, "Finnish Ventilation Regulations for Better IAQ and Energy Efficiency," in CLIMA 2016 proceedings of the 12th REHVA World Congress, 2016, vol. 5.

[8] J. Kurnitski et al., "Evidence based residential ventilation: sizing procedure and system solutions addressed by REHVA Residential Ventilation Task Force," E3S Web Conf., vol. 111, no. 01016, Aug. 2019.

[9] U. Palmiste, J. Kurnitski, and H. Voll, "Design criteria for outdoor air intakes and exhaust air outlets located on an external wall," E3S Web Conf., vol. 172, 2020.

[10] M. Luoma and K. Kovanen, "Odour Threshold of Kitchen Exhaust Air During Typical Cooking Situations In A Dwelling," in 13th AIVC Conference "Ventilation for Energy Efficiency and Optimum Indoor Air Quality," 1992, pp. 471-479.

[11] P. Broas, "Ventilation through building walls - wind tunnel studies," J. Wind Eng. Ind. Aerodyn., vol. 60, pp. 241-250, Apr. 1996.

[12] K. Kovanen, J. Heikkinen, and V. Siitonen, "Acceptability of wall exhaust discharges in residential ventilation," Build. Environ., vol. 29, no. 3, pp. 381-386, Jul. 1994.

[13] P. Broas, "Wind tunnel investigation of waste air re-entry with wall ventilation," WIT Trans. Ecol. Environ., vol. 1, pp. 479-486, 1993.

[14] C. A. Parker, K. D. Pressnail, M. F. Touchie, D. Derose, and S. Dedesko, "A Study of Cross Contamination of in-Suite Ventilation Systems Used in Multi-Unit Residential Buildings," in 14th Canadian Conference On Building Science and Technology, 2014, pp. 369-380.

[15] E. Sibille, "Optimized integration of ventilation with heat recovery in residential buildings through the implementation of innovative air distribution strategies and pre-fabricated components," 2015.

[16] B. M. Jones, M. J. Cook, S. D. Fitzgerald, and C. R. Iddon, "A review of ventilation opening area terminology," Energy Build., vol. 118, pp. 249-258, 2016.

[17] CEN (European Committee for
Standardization), “CEN/TR 16798-4. Energy performance of buildings - Ventilation for buildings - Part 4: Interpretation of the requirements in EN 16798- 3 - For nonresidential buildings - Performance requirements for ventilation and roomconditioning systems," Brussels, 2017. 